\title{
Correction: Hearts deficient in both Mfn1 and Mfn2 are protected against acute myocardial infarction
}

\author{
A. R. Hall, N. Burke, R. K. Dongworth, S. B. Kalkhoran, A. Dyson, J. M. Vicencio, G. W. Dornll, D. M. Yellon and D. J. Hausenloy
}

(c) The Author(s) 2021

Cell Death and Disease (2021)12:660; https://doi.org/10.1038/s41419-021-03946-8

Correction to: Cell Death and Disease https://doi.org/10.1038/ cddis.2016.139, published online 26 May 2016

The original version of this article unfortunately contained a mistake in an author name. The correct author name is GW Dorn $2^{\text {nd }}$. The original article has been corrected.

Open Access This article is licensed under a Creative Commons Attribution 4.0 International License, which permits use, sharing, adaptation, distribution and reproduction in any medium or format, as long as you give appropriate credit to the original author(s) and the source, provide a link to the Creative Commons license, and indicate if changes were made. The images or other third party material in this article are included in the article's Creative Commons license, unless indicated otherwise in a credit line to the material. If material is not included in the article's Creative Commons license and your intended use is not permitted by statutory regulation or exceeds the permitted use, you will need to obtain permission directly from the copyright holder. To view a copy of this license, visit http://creativecommons. org/licenses/by/4.0/.

(c) The Author(s) 2021 